\title{
Selection of sunflower genotypes for salt stress and mechanisms of salt tolerance in contrasting genotypes
}

\section{Seleção de genótipos de girassol ao estresse salino e mecanismos de tolerância ao sal em genótipos contrastantes}

\author{
André Dias de Azevedo Neto*(i) Katia Núbia Azevedo Barros Mota² (D), Petterson Costa Conceição Silva² (D), \\ Alide Mitsue Watanabe Cova² (D) Rogério Ferreira Ribas² ${ }^{(\mathbb{D})}$, Hans Raj Gheyi ${ }^{(\mathbb{D})}$
}

'Universidade Federal do Recôncavo da Bahia/UFRB, Centro de Ciências Exatas e Tecnológicas, Cruz das Almas, BA, Brasil

2Universidade Federal do Recôncavo da Bahia/UFRB, Centro de Ciências Agrárias, Ambientais e Biológicas, Cruz das Almas, BA, Brasil

*Corresponding author: azevedo_neto@yahoo.com.br

Received in July 13, 2020 and approved in September 21, 2020

\begin{abstract}
Salinity is one of the main limiting factors for crop growth. The metabolic responses to salt stress are variable and depend on species characteristics. This study aimed to select sunflower genotypes tolerant to salt stress and evaluate some mechanisms of salt tolerance in two contrasting (salt-tolerant and salt-sensitive) genotypes. In the first assay, the biomass production and the accumulation of $\mathrm{Na}^{+}$ and $\mathrm{K}^{+}$in 26 sunflower genotypes were evaluated. Genotypes AG963, AG967, AG972, BRS321, BRS324, H251, H360 and H863 showed lower biomass production and were characterized as salt-sensitive and the genotypes BRS323, Catisol, EXP11-26, EXP44-49, EXP60050, EXP887, HLA860HO and Olisun 5 showed higher biomass production and were considered salt-tolerant. The high $\mathrm{K}^{+}$content and the low $\mathrm{Na}^{+}$content in the leaves were the ion traits related to salt tolerance and can be used in sunflower breeding programs for this purpose. In the second assay, the plants of salt-tolerant BRS323 had lower $\mathrm{Na}^{+}$and $\mathrm{Cl}$ - contents and higher levels of $\mathrm{K}^{+}$than plants of salt-sensitive AG967. A better homeostasis in the mechanisms of transport, distribution and accumulation of inorganic solutes in conjunction with a more efficient osmoregulation mechanism through the synthesis of organic solutes may, at least in part, explain the greater salt-tolerance of BRS323 genotype in comparison to AG967.
\end{abstract}

Index terms: Helianthus annuus L.; genotypic variation; ion distribution; osmotic tolerance; abiotic stress.

\begin{abstract}
RESUMO
A salinidade é um dos principais fatores limitantes para o crescimento das culturas. As respostas metabólicas ao estresse salino são variáveis dependendo das características da espécie. O presente estudo teve como objetivo selecionar genótipos de girassol tolerantes ao estresse salino e avaliar alguns mecanismos de tolerância ao sal em dois genótipos contrastantes (tolerantes e sensíveis ao sal). No primeiro ensaio, foram avaliados a produção de biomassa e o acúmulo de $\mathrm{Na}^{+}$e K $\mathrm{K}^{+}$em 26 genótipos de girassol. Os genótipos AG963, AG967, AG972, BRS321, BRS324, H251, H360 e H863 apresentaram menor produção de biomassa e foram caracterizados como sensíveis ao sal e os genótipos BRS323, Catisol, EXP11-26, EXP44-49, EXP60050, EXP887, HLA860HO e Olisun 5 apresentaram maior produção de biomassa e foram considerados tolerantes ao sal. O alto teor de $\mathrm{K}^{+} \mathrm{e}$ o baixo teor de $\mathrm{Na}^{+}$nas folhas foram as características iônicas relacionados à tolerância ao sal e podem ser utilizados em programas de melhoramento de girassol para esse fim. No segundo ensaio, as plantas de BRS323 tolerantes ao sal apresentaram menor teor de $\mathrm{Na}^{+}$e $\mathrm{Cl}^{-}$e maiores níveis de $\mathrm{K}^{+}$do que as plantas de AG967 sensível ao sal. Uma melhor homeostase nos mecanismos de transporte, distribuição e acumulação de solutos inorgânicos em conjunto com um mecanismo de osmorregulação mais eficiente através da síntese de solutos orgânicos pode, ao menos em parte, explicar a maior tolerância ao sal do genótipo BRS323 em comparação com o AG967.
\end{abstract}

Termos para indexação: Helianthus annuus L.; variação genotípica; distribuição iônica; tolerância osmótica; estresse abiótico.

\section{INTRODUCTION}

In the Northeast region of Brazil, soil salinity is one of the main problems for the crop growth. Commonly, in arid and semi-arid regions, brackish water is used in irrigation, resulting in salinization of soils and reduced crop production (Melo et al., 2018).
The high concentration of salts in soils reduces the water uptake, inducing water stress, and inhibits the growth and development of plants (Isayenkov; Maathuis, 2019). The negative role of salt stress is caused mainly by osmotic and ionic effects. The osmotic effect is associated with the reduction in the free energy of water due to reduced 
osmotic potential outside the roots, impairing shoot growth (Rahnama et al., 2011; Shahzad et al., 2015). The ionic effect is characterized by a gradual accumulation of toxic ions (mainly $\mathrm{Na}^{+}$and $\mathrm{Cl}^{-}$) in plant tissue. This effect occurs slowly and can cause chlorosis, necrosis, and drying of old leaves (Rahnama et al., 2011; Hura et al., 2017).

Some mechanisms of salt-tolerance in plants can decrease $\mathrm{Na}^{+}$transport to young leaves, retaining toxic ions in lower tissues and old leaves. For example, ion sequestration by roots, partitioning of $\mathrm{Na}^{+}$in stems and petioles, compartmentalization of toxic ions in the vacuole, $\mathrm{Na}^{+}$exclusion from shoots, and the maintenance of $\mathrm{K}^{+}$in growing tissues include some mechanisms of salt-tolerance (Rahnama et al., 2011; Gerona et al., 2019).

For satisfactory crop production in salt-affected soils, an alternative approach is necessary, such as the choice of salt-tolerant crop varieties. The extensive genetic variability in plant species allows developing a good breeding program of new stress-tolerant genotypes (Sakina et al., 2016). Breeding of crops for salt tolerance has been studied for a long time and different methodologies have been used for this purpose based on the physiological responses of plants (Shahzad et al., 2015; Sakina et al., 2016; Cova et al., 2020).

There is a large genotypic variation related to $\mathrm{Na}^{+}$ and $\mathrm{K}^{+}$uptake and accumulation in some species, which can strongly modulate the biomass production (Rahnama et al., 2011; Gerona et al., 2019). Tolerant genotypes are more effective in reducing the concentration of toxic ions in photosynthetically active leaves than sensitive ones (Gerona et al., 2019). In wheat, studies verified that the reduction of $\mathrm{Na}^{+}$transport from root to shoot, $\mathrm{Na}^{+}$ sequestration in leaf sheath, lesser $\mathrm{Na}^{+}$accumulation and higher $\mathrm{K}^{+} / \mathrm{Na}^{+}$ratio in plant tissues under saline conditions are associated with the genotypic characteristic of salttolerance (Rahnama et al., 2011). These parameters have been used for screening salt-tolerant plants, mainly through multivariate analysis, as principal components analysis (PCA) and hierarchical cluster analysis (HCA), and the identified genotypes may be considered for inclusion in the breeding program and future genetic studies for salttolerance (Sarabi et al., 2016).

Loss of water from the cells is another recurrent problem for plants cultivated under salinity. To maintain turgor and cell volume under this condition, plants perform the osmotic adjustment, which involves the accumulation of organic solutes of low molecular mass, such as soluble carbohydrates, proline, amino acids, and quaternary ammonium compounds (Cova et al., 2020; van Zelm; Zhang; Testerink, 2020). The accumulation of organic solutes, in addition to osmotic adjustment, also contributes to the protection of macromolecule and membranes from the deleterious effects of salinity (Silva; Azevedo Neto; Gheyi, 2019). Plant species and varieties differ in the accumulation of compatible solutes, which promotes changes in the relative contribution during osmotic adjustment (Rhodes; Nadolska-Orczyk; Rich, 2002). In addition, the allocation of organic and inorganic solutes in different organs and the distribution of the ions in leaf tissues of different developmental stages can be a new approach for selection of genotypes to salt tolerance.

Sunflower is an oilseed crop used for the production of quality biofuel and for human and animal food (Machekposhti et al., 2017; Birck et al., 2017). In Brazil, in 2019 the cultivated area under this crop was 80,818 hectares with a production of $131,173 \mathrm{Mg}$ achenes (Instituto Brasileiro de Geografia e Estatística - IBGE, 2019). This crop, is an alternative for crop rotation and succession in several producing regions because it adapts to different latitude, longitude and photoperiod (Birck et al., 2017). However, its tolerance to salt stress varies according to the genetic material. Li et al. (2020) observed that out of 552 sunflower genotypes, only 30 were considered to be highly tolerant and 53 tolerant to salt in the germination phase under $300 \mathrm{mM} \mathrm{NaCl}$. For the genotype $H$. annuus L. cv. Azargol the threshold soil salinity was $1.6 \mathrm{dS} \mathrm{m}^{-1}$ for oil production (Machekposhti et al., 2017). In case of cultivar Embrapa 122/V-2000, Nobre et al. (2011) observed linear decreases in the leaf area, dry matter of the aerial parts and roots, production of achenes and the harvest index when electrical conductivity of irrigation water (ECw) exceeded $0.5 \mathrm{dS} \mathrm{m}^{-1}$. For the same genotype, productivity decreased by $119.93 \mathrm{~kg} \mathrm{ha}^{-1}$ with per unit increment of ECw (Santos et al., 2016). Therefore, this study aimed to select sunflower genotypes tolerant to salt stress and to evaluate the mechanisms of salt tolerance in two contrasting (salt-tolerant and salt-sensitive) genotypes, through the accumulation and distribution of inorganic and organic solutes in the distinct organs and pairs of leaves of different age.

\section{MATERIAL AND METHODS}

The study was carried out in a greenhouse with mean values of air temperature, relative air humidity, and photosynthetic active radiation (at noon) of $34{ }^{\circ} \mathrm{C}, 65 \%$, and $1200 \mu \mathrm{mol} \mathrm{m}^{-2} \mathrm{~s}^{-1}$, respectively. Two experiments were carried out: the first one in a completely randomized design, a 26 (genotypes) $\times 2$ (salt levels -0 and $100 \mathrm{mM}$ $\mathrm{NaCl}$ ) factorial with four replicates, and the second one in 
a completely randomized design, a 2 (genotypes) $\times 2$ (salt levels -0 and $100 \mathrm{mM} \mathrm{NaCl}$ ) factorial with five replicates.

\section{Assay 1: Selection of sunflower genotypes differing in salt tolerance}

Seeds of 26 sunflower genotypes were obtained from six different companies: Ceapar (AG862, AG963, AG967, AG972, AG975); Embrapa Soja (BRS321, BRS322, BRS323, BRS324, BRS-G27), Coordenadoria de Assistência Técnica Integral (Catissol), Helianthus do Brasil (EXP11-26, EXP44-49, EXP44-63, EXP60050, EXP887, H250, H251, H358, H360, H863, HLA860HO, TC8122), Instituto Agronômico de Campinas (IACUruguai), and Atlântica sementes (Olisum 3, Olisum 5).

Seeds were surface-sterilized with $2 \%$ sodium hypochlorite for five minutes and then washed three times with distilled water for three minutes each. Sterilized seeds were sown in 200-mL plastic recipients containing washed sand and irrigated with half-strength Hoagland's nutrient solution (Hoagland; Arnon, 1950). Seven days after germination, the seedlings were transferred to plastic containers with 12-L of aerated full-strength Hoagland's nutrient solution in a Floating hydroponic system. The nutrient solutions were renewed weekly and daily volume was completed with distilled water. The $\mathrm{pH}$ was daily monitored and adjusted to between 6.0 and 6.5 with $1.0 \mathrm{M}$ hydrochloric acid $(\mathrm{HCl})$ or $1.0 \mathrm{M}$ sodium hydroxide $(\mathrm{NaOH})$.

After eight days under these conditions, the seedlings received their respective salt-treatments (Control (C) - nutrient solution without $\mathrm{NaCl}$ or salt stress (S) nutrient solution with $100 \mathrm{mM} \mathrm{NaCl}$ ). $\mathrm{NaCl}$ was gradually added $\left(25 \mathrm{mM} \mathrm{day}^{-1}\right)$ to avoid osmotic shock. Plants were harvested at ten days after the end of salt additions.

At the harvest, the plants of all treatments were carefully removed from the nutrient solution. The roots were washed with distilled water and plants were divided into leaves, stems, and roots. After drying at $65^{\circ} \mathrm{C}$ in an oven for $72 \mathrm{~h}$, the dry masses of the leaf (LDM), stem (SDM), and root (RDM) were determined and the total dry mass (TDM) was calculated by summation. Data of dry mass yield in different plant organs were expressed as a percentage relative to control, using the formula: $\%$ of control $=100-\left(\mathrm{DM}_{\mathrm{S}} \times 100\right) / \mathrm{DM}_{\mathrm{C}}$, where:

$\mathrm{DM}_{\mathrm{C}}=$ dry mass yield of the leaves, stems or roots in the control treatment;

$\mathrm{DM}_{\mathrm{s}}=$ dry mass yield of the leaves, stems or roots in the salt stress treatment.

For the determination of $\mathrm{Na}^{+}$and $\mathrm{K}^{+}$contents in leaves, stems, and roots, the extracts were prepared as described by Gondim et al. (2011). In test tubes, $0.1 \mathrm{~g}$ dried powdered plant material and $10 \mathrm{~mL}$ deionized water were added. The tubes were heated to $95^{\circ} \mathrm{C}$ in a water bath for one hour and then centrifuged at $5.000 \times \mathrm{g}$ for five minutes. The supernatants were filtered in quantitative filter paper, collected and stored at $-20^{\circ} \mathrm{C}$ for further analysis. The $\mathrm{Na}^{+}$ and $\mathrm{K}^{+}$contents were determined by flame photometry (Jones Jr., 2001).

\section{Assay 2: Inorganic and organic solutes in salt- tolerant and salt-sensitive sunflower genotypes}

This assay was carried out using seeds of two contrasting genotypes (BRS323 and AG967) selected from the first assay and respectively classified as salttolerant and salt-sensitive. The treatment of seeds, sowing, production of seedlings, cultivation system, salt-treatments and the management of nutrient solutions were the same as that of Assay 1. Plants remained under salt stress for 20 days, and after this period, were harvested and divided into leaves, stems, and roots for the determination of organic and inorganic solutes content.

Samples (about 1 to $2 \mathrm{~g}$ ) of the first pair of fully expanded leaves and the younger third of the root system were collected, immediately frozen in liquid $\mathrm{N}_{2}$ and lyophilized for analysis of organic solutes (soluble carbohydrates, free amino acids, soluble proteins, and free proline) content. Extract preparation and determination of organic solutes were carried out as described by Sacramento et al. (2014). The soluble carbohydrates were determined at $490 \mathrm{~nm}$, by sulfuric acid-phenol method. Free amino acids were determined at $570 \mathrm{~nm}$, by ninhydrin method, and the proline was determined at $520 \mathrm{~nm}$, by acid-ninhydrin method. Soluble proteins were determined at $595 \mathrm{~nm}$ by proteindye binding method.

Samples (about 1 to $2 \mathrm{~g}$ ) of the $6^{\text {th }}, 7^{\text {th }}, 8^{\text {th }}$, and $9^{\text {th }}$ pairs of fully expanded leaves, counted from of base of the stem, were collected separately for analysis of $\mathrm{Na}^{+}, \mathrm{K}^{+}$, and $\mathrm{Cl}^{-}$content (inorganic solutes) in leaves of different age. The remaining plant material was oven-dried at $65{ }^{\circ} \mathrm{C}$ for $72 \mathrm{~h}$ and ground to a powder for analysis of the concentrations of $\mathrm{Na}^{+}, \mathrm{K}^{+}$, and $\mathrm{Cl}^{-}$in different organs (leaves, stems and roots). The extracts for determination of $\mathrm{Na}^{+}, \mathrm{K}^{+}$, and $\mathrm{Cl}^{-}$contents in leaves were prepared as described in Assay 1. $\mathrm{Na}^{+}$and $\mathrm{K}^{+}$were determined by flame photometry, and $\mathrm{Cl}^{-}$content by spectrophotometry (Jones Jr., 2001).

\section{Statistical analysis}

In Assay 1, the results were subjected to analysis of variance (F test) and the means were compared by the 
Scott-Knott's test at 0.05 probability, using the Sisvar 5.6 statistical software (Ferreira, 2019).

Principal components analysis (PCA) for traits of this assay (TDM, $\mathrm{Na}^{+}$and $\mathrm{K}^{+}$) was performed using the R Statistical Software (R Statistical Software - R Core Team, 2020), following the use of the 'cluster' and 'dendextend' packages (Galili, 2015; Maechler et al., 2019) for application of hierarchical cluster analysis (HCA) by the 'Ward' method. For the visualization of the obtained results, the 'factoextra' $R$ package was used (Kassambara; Mundt, 2020).

In Assay 2, the results were subjected to analysis of variance (F-test) and the means were compared by Tukey's test at 0.05 probability, using the Sisvar 5.6 statistical software (Ferreira, 2019).

\section{RESULTS AND DISCUSSION}

In general, the biomass of all sunflower genotypes studied was reduced by salt stress, and Figure 1 shows the relative biomass production of salt-stressed genotypes in comparison to their respective control. The lowest values of LDM (60 to 75\%) were observed in the genotypes: AG862, AG963, AG967, AG972, BRS321, BRS324, BRS-G27, EXP44-63, H251, H360, H863, TC 8122 and Olisum 3 under salinity (Figure 1A). In contrast, the highest values of LDM (77 to 95\%) were observed in AG975, BRS322, BRS323, Catisol, EXP11-26, EXP4449, EXP60050, EXP887, H250, H358, HLA860HO, IAC-Uruguai and Olisum 5.

Also, the lowest relative productions of SDM (41 to $66 \%$ ) were found in the genotypes: AG862, AG963, AG967, AG972, BRS321, BRS324, BRS-G27, Catisol, EXP44-49, EXP44-63, EXP887, H250, H251, H360, H863, TC 8122 and Olisun 3 under salinity, while the genotypes AG975, BRS323, EXP11-26 and Olisum 5 showed the highest relative production of SDM (83 to 93\%) in comparison to control conditions (Figure 1B).

Compared to the control, the genotypes: AG862, AG963, AG967, AG972, AG975, BRS321, BRS322, H250, H251, H358, H360, H863, IAC-Uruguai and Olisun 3 had the lowest RDM values (62 to 79\%) (Figure 1C). On the other hand, the relative productions of RDM in EXP44-49, EXP887, and HLA860HO genotypes were not affected by salt stress.

Also, the genotypes BRS323, Catisol, EXP1126, EXP44-49, EXP60050, EXP887, HLA860HO and Olisun 5 showed the highest relative productions of TDM (83 to 93\%) under salt stress in comparison to control conditions (Figure 1D). The most salt-affected genotypes were AG963, AG967, AG972, BRS321, BRS324, H251, $\mathrm{H} 360$, and H863, which showed relative productions of TDM ranging from 55 to $68 \%$.

The variation in salt tolerance among genotypes of the same species is commonly reported in the literature (Shtereva; Vassilevska-Ivanova; Karceva, 2015), and the use of salt-tolerant cultivars is more economically viable than the techniques for reclamation of the salt-affected areas (Liang et al., 2018). According to Munns (2002), the relative production of biomass is a valid indicator of salt tolerance in plants, so the criterion used to classify the genotypes as salt-tolerant or salt-sensitive was the relative dry mass yield.

Salinity strongly increased $\mathrm{Na}^{+}$content in all plant parts (Table 1). In leaves of salt-stressed plants, $\mathrm{Na}^{+}$content varied among genotypes. The lowest values were observed in IAC-Uruguai, BRS322, EXP60050, AG975, Catisol, EXP44-49, H250 and BRS323, and the highest $\mathrm{Na}^{+}$content in AG967. A significant variation in $\mathrm{Na}^{+}$content among the genotypes under salt stress was also observed in stem ( 3.30 to $\left.4.07 \mathrm{mmol} \mathrm{g}^{-1} \mathrm{DM}\right)$ and roots $\left(4.14\right.$ to $\left.5.20 \mathrm{mmol} \mathrm{g}^{-1} \mathrm{DM}\right)$. In roots, the lowest values were found in the genotypes IAC-Uruguai, Olisun 3, EXP60050, H358, AG963, EXP11-26, HLA860HO, $\mathrm{H} 251$ and $\mathrm{H} 250$, and the higher values in H360, BRS323, AG972, BRS324, and BRS-G27.

In the salt stress treatment, a significant variation between the $\mathrm{Na}^{+}$and $\mathrm{K}^{+}$levels in the plant organs of the genotypes was observed. However, it is noteworthy that in the leaves of the genotypes classified as salt-sensitive the highest $\mathrm{Na}^{+}$and the lowest $\mathrm{K}^{+}$levels were observed, in contrast to the leaves of tolerant ones, which showed the lowest $\mathrm{Na}^{+}$and the highest $\mathrm{K}^{+}$contents. However, in the stem and roots, no relationship was observed between the accumulation of these ions and the degree of salt tolerance.

Principal component analysis (PCA) showed that $\mathrm{PC} 1$ and $\mathrm{PC} 2$ together explained $94.17 \%$ of the variance (Figure 2A). PC1 explained the largest variance observed in the data $(79.29 \%$ ), while PC2 accounted for $14.88 \%$ of the total variance. In this figure, it is possible to see the dispersion of the variables according to the score and the correlation between them. Considering that the cosine of the angle between any two vectors representing variables indicates the coefficient of correlation between those variables (Jolliffe; Cadima, 2016), the leaf $\mathrm{K}^{+}$content and TDM correlated positively, in contrast to the leaf $\mathrm{Na}^{+}$ content, which showed a negative correlation with the dry mass yield. 


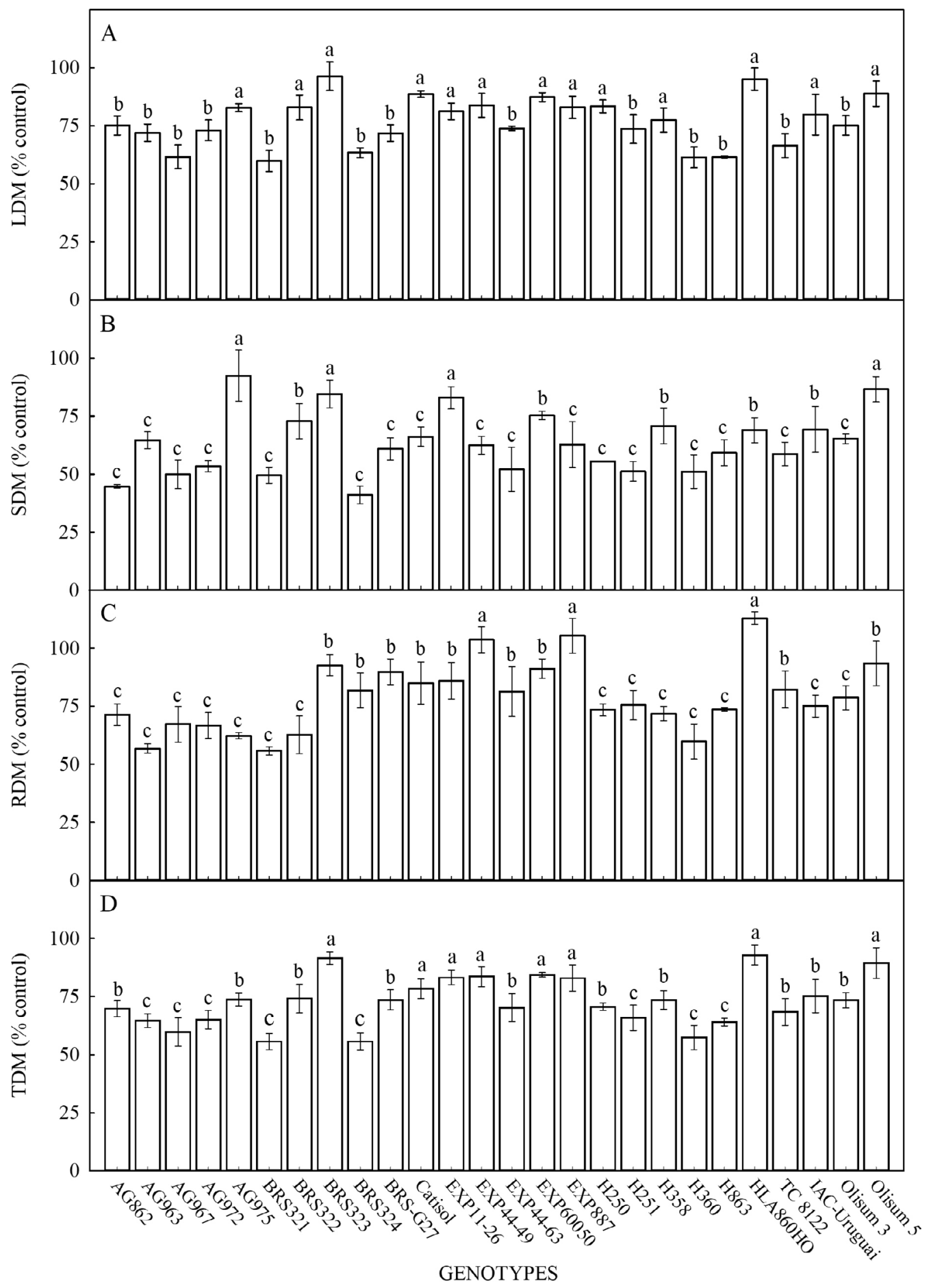

Figure 1: Dry mass yield, expressed as percentage of the control, of leaf - LDM (A), stem - SDM (B), root - RDM (C) and total - TDM (D) of 26 sunflower genotypes grown under greenhouse conditions for ten days in nutrient solution containing $100 \mathrm{mM}$ of $\mathrm{NaCl}$.

Means followed by the same letters do not significantly differ by the Scott-Knott's test at $p \leq 0.05$. Vertical bars represent the standard errors $(n=4)$. 
Table 1: Content of sodium and potassium ( $\left.\mathrm{mmol} \mathrm{g}^{-1} \mathrm{DM}\right)$ in leaves, stems and roots of 26 sunflower genotypes grown under greenhouse conditions for ten days with nutrient solution (control - C) or nutrient solution containing $100 \mathrm{mM} \mathrm{NaCl}$ (salt stress - S).

\begin{tabular}{|c|c|c|c|c|c|c|}
\hline \multirow[b]{2}{*}{ Genotypes } & \multicolumn{2}{|c|}{---------------Leaves-------------- } & \multicolumn{2}{|c|}{----------------Stem--------------- } & \multicolumn{2}{|c|}{----------------Roots--------------- } \\
\hline & C & S & C & $\mathrm{S}$ & $\mathrm{C}$ & S \\
\hline & \multicolumn{6}{|c|}{ - } \\
\hline AG862 & $0.01 \mathrm{Ab}(0.000)$ & 2.19Ea (0.143) & $0.25 \mathrm{Ab}(0.028)$ & 3.76Aa (0.144) & $1.24 \mathrm{Ab}(0.043)$ & 4.67Ca (0.157) \\
\hline AG963 & $0.02 \mathrm{Ab}(0.002)$ & $2.72 \mathrm{Ca}(0.149)$ & $0.23 \mathrm{Ab}(0.028)$ & 3.47Ba (0.203) & $1.16 \mathrm{Ab}(0.084)$ & 4.42Da (0.164) \\
\hline AG967 & $0.01 \mathrm{Ab}(0.001)$ & 3.23Aa (0.070) & $.21 \mathrm{Ab}(0.023)$ & 63Aa (0.031) & $1.23 \mathrm{Ab}(0.037)$ & $4.52 \mathrm{Ca}(0$. \\
\hline AG972 & $0.01 \mathrm{Ab}(0.000)$ & 2.15Ea (0.153) & $0.17 \mathrm{Ab}(0.014)$ & 3.85Aa (0.171) & $1.36 \mathrm{Ab}(0.046)$ & 5.14Aa (0.223) \\
\hline AG975 & $\mathrm{b}(0.000)$ & 2.02Ea (C & 009) & 32) & $1.59 \mathrm{Ab}(0.0$ & 4.75Ba \\
\hline BRS321 & $0.01 \mathrm{Ab}(0.000)$ & $2.61 \mathrm{Ca}(0.126)$ & $0.16 \mathrm{Ab}(0$ & 3.43Ba (0.066) & $1.02 \mathrm{Bb}(0.080)$ & 4.87Ba $(0.2$ \\
\hline & $0.01 \mathrm{Ab}(0.000)$ & 1.73Fa (0.157) & $.13 A b($ & 3.38Ba (0.063) & $0.91 \mathrm{Bb}(0.042)$ & $4.62 \mathrm{Ca}(0$. \\
\hline BRS323 & $0.01 \mathrm{Ab}(0.001)$ & 1.60Fa (0.082) & $0.15 \mathrm{Ab}(0 . \mathrm{C}$ & 3.86Aa (0.182) & $1.35 \mathrm{Ab}(0.116)$ & 5.01Aa (0.109) \\
\hline & $01 \mathrm{Ab}(0.000)$ & $2.41 \mathrm{Da}(0$. & $0.16 \mathrm{Ab}$ & 4.07Aa (0.264) & $1.11 \mathrm{Bb}(0.082)$ & 5.16Aa (0 \\
\hline BRS & $\mathrm{b}(0.001)$ & 2.3 & $19 A b$ & 87) & $1.20 \mathrm{Ab}$ & $5.20 \mathrm{Aa}$ \\
\hline Catis & $0.01 \mathrm{Ab}(0.000)$ & 1.60Fa (C & $0.17 A b$ & 96) & $1.22 \mathrm{Ab}(0.085)$ & $4.85 \mathrm{Ba}(0$ \\
\hline & 0.01 & & & & & \\
\hline EXP4 & $b(0.001)$ & 1.67Fa (0 & $0.18 \mathrm{Ab}($ & 01) & $1.02 \mathrm{Bb}(0 . \mathrm{C}$ & $4.54 \mathrm{Ca}(\mathrm{C}$ \\
\hline & 0.01 & 2.0 & & & & $0)$ \\
\hline EXP60050 & $(0.001)$ & $1.79 \mathrm{~F}$ & $0.22 A$ & 2) & 1.28 & 4.41Da ( \\
\hline XP887 & $0.01 \mathrm{Ab}(0$. & 2.03Ea (C & $0.19 A b($ & 14) & $1.09 \mathrm{Bb}$ & $4.82 \mathrm{Ba}$ \\
\hline & & & & & & \\
\hline $\mathrm{H} 251$ & $0.02 \mathrm{Ab}(0$. & $2.62 C$ & $0.16 \mathrm{~A}$ & 73) & $1.61 \mathrm{Ab}$ & $4.20 \mathrm{Da}($ \\
\hline & & & & & & 5) \\
\hline H360 & 0.02 & & & & & \\
\hline H863 & 0.02 & 2.9 & & & $1.22 \mathrm{~A}$ & $4.82 \mathrm{Ba}$ \\
\hline HLA860HO & $0.02 A$ & & & & & 4.39Da \\
\hline 8122 & (0.001) & $2.45 \mathrm{Da}(0$ & $0.12 \mathrm{Ab}($ & 3.32Ba ( & $0.82 \mathrm{Bb}(0.031)$ & 4.65Ca (C \\
\hline IAC- & 02) & & & & & 4.40Da \\
\hline Olisum 3 & $0.01 \mathrm{~A}$ & 2.37 & $0.13 \mathrm{Ab}($ & 9) & 1.1 & 4.31Da \\
\hline \multirow[t]{2}{*}{ Olisum 5} & $0.01 \mathrm{Ab}(0.000)$ & 1.93Ea $(0.195)$ & $0.11 \mathrm{Ab}(0.010)$ & 3.30Ba (0.219) & $0.77 \mathrm{Bb}(0.073)$ & $4.66 \mathrm{Ca}(0.121)$ \\
\hline & \multicolumn{6}{|c|}{ - } \\
\hline & $0.60 \mathrm{Aa}(0.008)$ & $0.55 \mathrm{Ba}(0.040)$ & & & & $0.58 \mathrm{Ba}(0.032)$ \\
\hline & $0.64 \mathrm{Aa}(0.023)$ & $0.56 \mathrm{Ba}(0.025)$ & $0.49 \mathrm{Da}(0.021)$ & & $0.50 \mathrm{Ca}(0.036)$ & $0.58 \mathrm{Ba}(0$. \\
\hline AG967 & $0.61 \mathrm{Aa}(0.022)$ & $0.53 \mathrm{Ba}(0.016)$ & 0.75Ba (0.055) & $0.81 \mathrm{Aa}(0.023)$ & $0.49 \mathrm{Cb}(0.010)$ & $0.63 \mathrm{Ba}(0.028)$ \\
\hline AG972 & $0.60 \mathrm{Aa}(0.015)$ & $0.58 \mathrm{Ba}(0.043)$ & $0.60 \mathrm{Ca}(0.030)$ & 0.59Ba $(0.061)$ & $0.46 \mathrm{Ca}(0.026)$ & $0.52 \mathrm{Ca}(0.037)$ \\
\hline AG975 & $0.60 \mathrm{Aa}(0.018)$ & 0.57Ва (0.046) & 0.69Ba (0.043) & $0.74 \mathrm{Aa}(0.056)$ & $0.54 \mathrm{Cb}(0.038)$ & $0.63 \mathrm{Ba}(0.047)$ \\
\hline BRS321 & $0.60 \mathrm{Aa}(0.055)$ & $0.52 \mathrm{Ba}(0.027)$ & $0.82 \mathrm{Aa}(0.031)$ & $0.75 \mathrm{Aa}(0.027)$ & $0.65 \mathrm{Ab}(0.017)$ & 0.77Aa (0.061) \\
\hline BRS322 & $0.58 \mathrm{Aa}(0.021)$ & $0.53 \mathrm{Ba}(0.038)$ & $0.45 \mathrm{Da}(0.035)$ & $0.53 \mathrm{Ca}(0.021)$ & $0.45 \mathrm{Ca}(0.028)$ & $0.50 \mathrm{Ca}(0.011)$ \\
\hline BRS323 & $0.61 \mathrm{Aa}(0.024)$ & $0.68 \mathrm{Aa}(0.043)$ & $0.72 \mathrm{Ba}(0.034)$ & $0.70 \mathrm{Aa}(0.048)$ & $0.45 \mathrm{Ca}(0.019)$ & 0.40Da (0.010) \\
\hline BRS324 & $0.66 \mathrm{Aa}(0.024)$ & $0.60 \mathrm{Ba}(0.041)$ & $0.62 \mathrm{Ca}(0.049)$ & $0.64 \mathrm{Ba}(0.025)$ & $0.48 \mathrm{Ca}(0.027)$ & $0.51 \mathrm{Ca}(0.017)$ \\
\hline
\end{tabular}


Table 1: Continuation.

\begin{tabular}{|c|c|c|c|c|c|c|}
\hline \multirow[b]{2}{*}{ Genotypes } & \multicolumn{2}{|c|}{----------------Leaves--------------- } & \multicolumn{2}{|c|}{------------------Stem----------------- } & \multicolumn{2}{|c|}{ 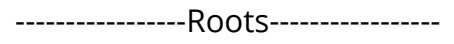 } \\
\hline & C & $S$ & C & $S$ & C & $\mathrm{s}$ \\
\hline & $0.66 \mathrm{Aa}(0.020)$ & $0.033)$ & $55 \mathrm{Da}(0.042)$ & $63 \mathrm{Ba}(0.051)$ & 0 & 0 \\
\hline & & & & & & \\
\hline & & & 35) & $0)$ & & \\
\hline & & & $0.026)$ & 0) & 6) & $0.70 \mathrm{Aa}(0$. \\
\hline & & & & & & \\
\hline & & & & & & \\
\hline & & & & & & \\
\hline & & 0.57 & $0.48 \mathrm{D}$ & & & \\
\hline $\mathrm{H} 251$ & $0.62 \mathrm{Aa}(0.008)$ & 0.57Ba (0.081) & $0.55 \mathrm{Da}(0.051)$ & $0.53 \mathrm{Ca}(0.0$ & & 0.47Ca ( \\
\hline & $0.58 \mathrm{Aa}(0.014)$ & 0.52Ba (0.016) & $0.53 \mathrm{Da}(0.016)$ & $0.48 \mathrm{Ca}(0.034)$ & & 0.69Aa (C \\
\hline & & & $0.53 \mathrm{Da}(0.040)$ & & & $0.63 \mathrm{Ba}(\mathrm{C}$ \\
\hline H863 & $0.63 \mathrm{Aa}(0.023)$ & 0.55Ba (0.040) & $0.74 \mathrm{Ba}(0.024)$ & 0.63Ba (0.037) & $0.57 \mathrm{Bb}(0.026)$ & 0.67Ba (0.009) \\
\hline HLA860HC & $0.63 \mathrm{Aa}(0.012)$ & $0.71 \mathrm{Aa}(0.055)$ & $0.70 \mathrm{Ba}(0.025)$ & $0.52 \mathrm{Cb}(0.033)$ & $0.50 \mathrm{Ca}(0.0$ & $0.54 \mathrm{Ca}(0.035)$ \\
\hline TC 8 & 0.66Aa (0.056) & $0.62 \mathrm{Aa}(0.045)$ & $0.55 \mathrm{Da}(0.038)$ & $0.52 \mathrm{Ca}(0.040)$ & $0.50 \mathrm{Ca}(0.030)$ & $0.55 \mathrm{Ca}(0.026)$ \\
\hline IAC-Uruguai & 0.64Aa (0.019) & 0.64Aa (0.070) & $0.58 \mathrm{Ca}(0.041)$ & $0.49 \mathrm{Ca}(0.105)$ & 0.47Ca (0.043) & $0.52 \mathrm{Ca}(0.008)$ \\
\hline Olisum 3 & $0.60 \mathrm{Aa}(0.029)$ & 0.60Ba (0. & $0.48 \mathrm{Da}(0.019)$ & $0.51 \mathrm{Ca}(0.019)$ & & $0.39 \mathrm{Da}(0.038)$ \\
\hline Olisum 5 & 0.63Aa (0.051) & 0.67Aa (0.040) & 0.50Da (0.030) & $0.40 \mathrm{Ca}(0.013)$ & $0.49 \mathrm{Ca}(0.018)$ & $0.55 \mathrm{Ca}(0.022)$ \\
\hline
\end{tabular}

In each plant organ, means followed by the same capital letters in a column and same lowercase letters in a row do not significantly differ by the Scott-Knott's test $(p \leq 0.05)$. Numbers between parentheses represent standard errors $(n=4)$.
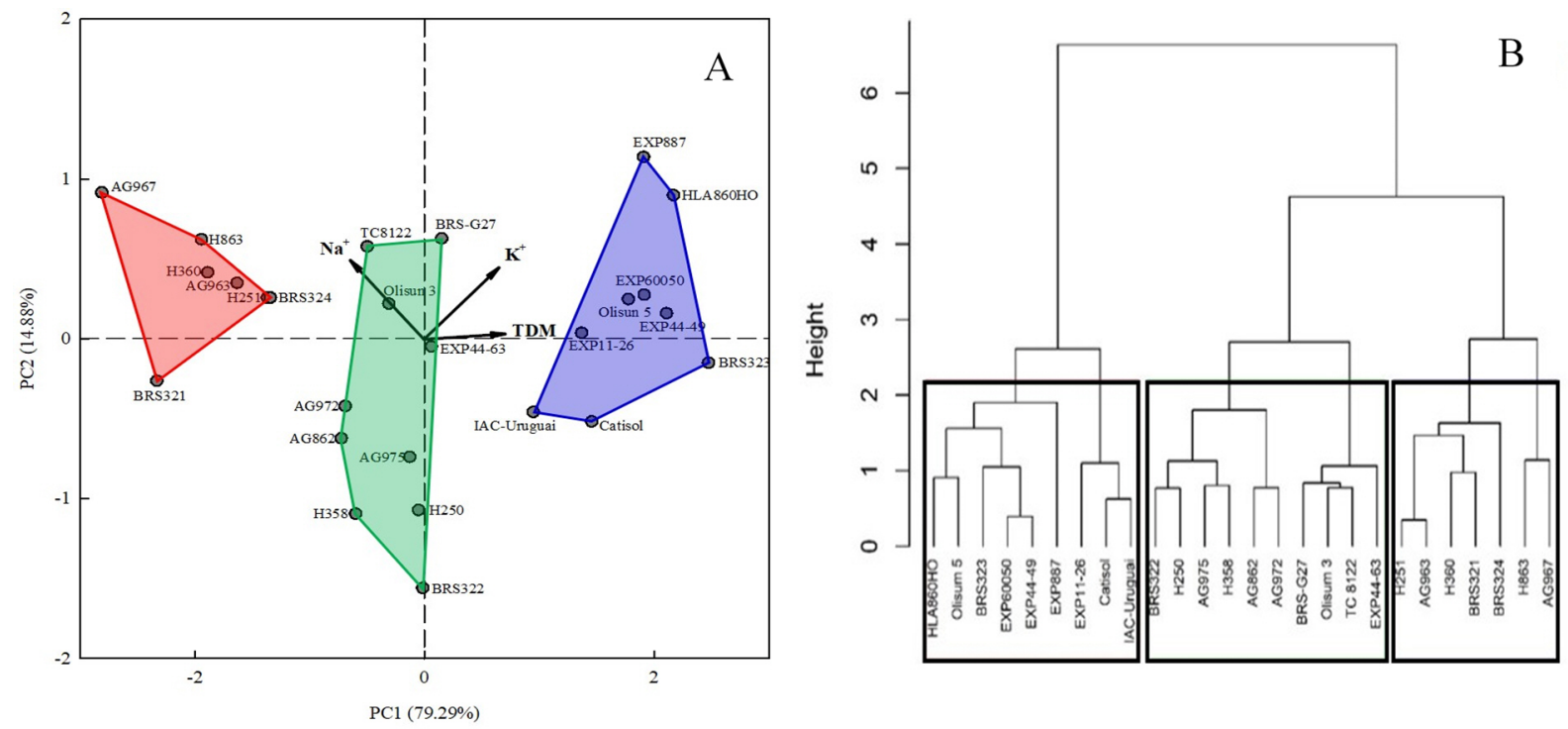

Figure 2: (A) Principal components analysis (PCA) using the leaf contents of sodium $\left(\mathrm{Na}^{+}\right)$and potassium $\left(\mathrm{K}^{+}\right)$and relative production of total dry mass (TDM) of 26 sunflower genotypes grown under greenhouse conditions for ten days in nutrient solution containing $100 \mathrm{mM} \mathrm{NaCl}$; and (B) dendrogram of hierarchical cluster analysis (HCA) by the 'Ward' method of the studied variables $\left(\mathrm{Na}^{+}, \mathrm{K}^{+}\right.$and TDM). 
Hierarchical cluster analysis (HCA) divided the genotypes into three groups, estimated by 'Ward' method based on Euclidian distance (Figure 2B). The first cluster (on the left) included all genotypes with the highest TDM (Figure 1D), plus the genotype IAC-Uruguai. On the opposite side (on the right), the third cluster included the genotypes with the lowest TDM, except the AG972.

In agreement with $\mathrm{HCA}$, the correlations of the $\mathrm{PC} 1$ axis discriminate against the groups of genotypes with higher and lower dry mass production. The right side of the PC1 gathered nine sunflower genotypes (BRS323, Catisol, EXP11-26, EXP44-49, EXP60050, EXP887, HLA860HO, IAC-Uruguai, and Olisun 5), which expressed high TDM, high leaf $\mathrm{K}^{+}$content and low leaf $\mathrm{Na}^{+}$content. By contrast, the left side of the PC1 associated seven genotypes (AG963, AG967, BRS321, BRS324, H251, H360, and H863) with opposite traits. It can also be seen in Figure 2A that BRS323 and AG967 genotypes occupy the most extreme positions on the $\mathrm{PC} 1$ axis.

The combinations of the HCA and PCA have been used to distinguish salt-tolerant cultivars from saltsensitive ones (Sarabi et al., 2016). These analyses were also used to evaluate the drought tolerance level of 49 switchgrass genotypes (Liu et al., 2015). In our study, PC1 was the main salt-related component, so the salt-tolerant genotypes (high TDM) are located on the right side of Figure 2A and the salt-sensitive ones on the left side (low TDM). Therefore, HCA and PCA contributed to explaining that the degree of salt-tolerance in sunflower is associated with the concentrations of $\mathrm{Na}^{+}$and $\mathrm{K}^{+}$in the leaves. The genotypes located on the extreme sides of the PC1 axis, BRS323 and AG967, were used in assay 2 as the most salt-tolerant and the most salt-sensitive, respectively.

Figure 3 shows the dry mass yield of two sunflower genotypes (BRS323 and AG967) that were selected in assay 1 as most salt-tolerant and most salt-sensitive, respectively. In assay 2, salinity decreased LDM (43\%), SDM (56\%), RDM (52\%), and TDM (50\%) of AG967 in comparison to control conditions. However, in BRS323, salinity induced a smaller reduction in RDM (26\%) and TDM $(21 \%)$ and did not affect the LDM and SDM, in contrast to results of assay 1. It can also be seen in Figure 3 that the dry mass yields of both genotypes were similar under control conditions. However, under salt stress, the LDM, SDM, RDM, and TDM of the BRS323 genotype were, respectively, 37, 87, 67 , and $61 \%$ higher than those of AG967.

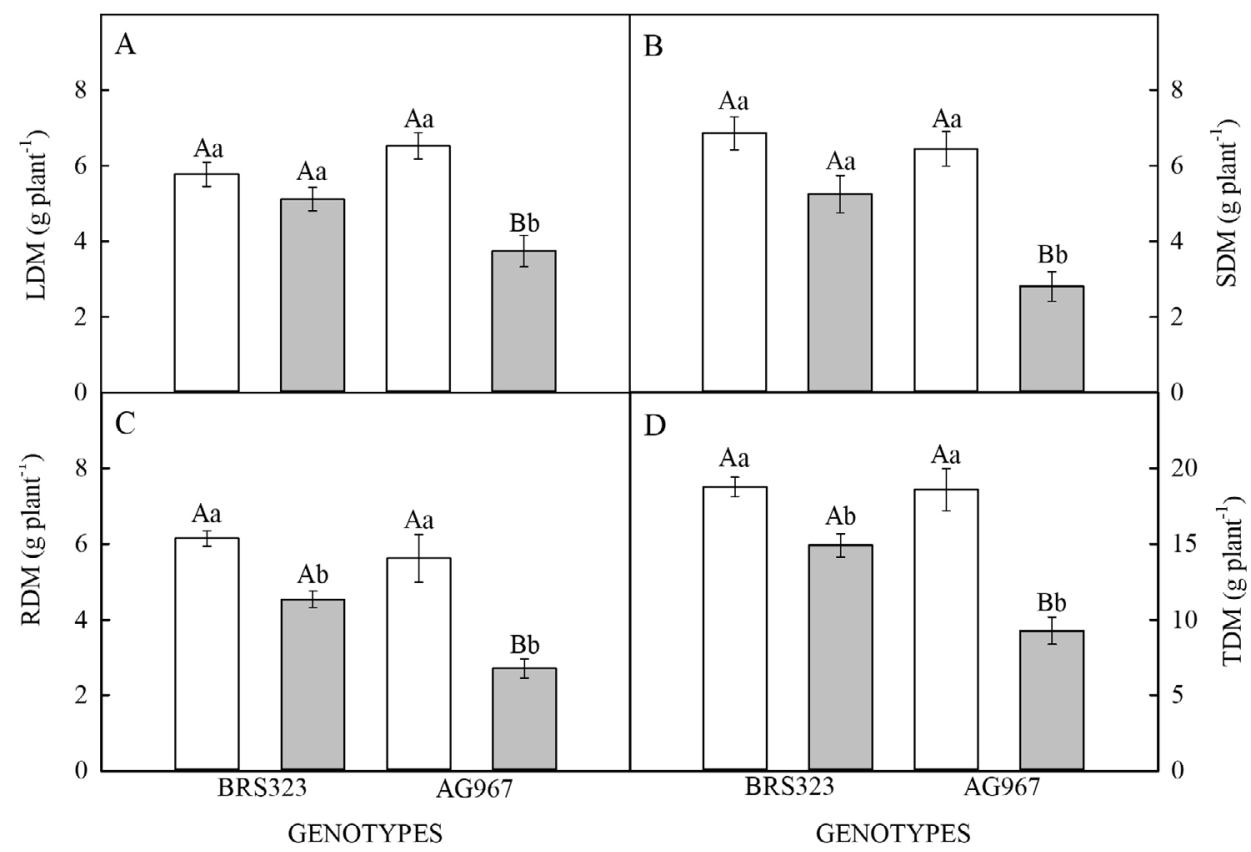

Figure 3: Leaf - LDM (A), stem - SDM (B), root - RDM (C) and total - TDM (D) dry mass yield of two sunflower genotypes grown under greenhouse conditions for 20 days in nutrient solution - control ( $\square$ ) or nutrient solution

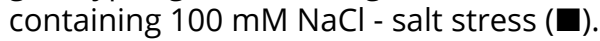

Means followed by the same letters do not significantly differ by the Tukey's test at $p \leq 0.05$. Uppercase letters compare genotypes at same salt levels and lowercase letters compare salt levels in same genotype. Vertical bars represent the standard errors ( $n=4)$. 
These results support the findings that BRS323 is a salt-tolerant genotype and that AG967 is a saltsensitive one. The most widely accepted explanations for the salt-induced biomass reduction are associated with a combination of factors such as water stress due to a reduction of osmotic potential, accumulation of $\mathrm{Na}^{+}$and $\mathrm{Cl}^{-}$toxic ions in plant tissues and imbalance of nutritional status (Shtereva; Vassilevska-Ivanova; Karceva, 2015).

Salinity increased the contents of $\mathrm{Na}^{+}$and $\mathrm{Cl}^{-}$in leaves, stems and roots of both genotypes (Figure 4). In salt-stressed leaves, the $\mathrm{Na}^{+}$content in the AG967 genotype was $52 \%$ higher than in BRS323 (Figure 4A). On the other hand, in the stem and roots, the $\mathrm{Na}^{+}$contents in BRS323 were, respectively, 73 and $20 \%$ higher than in AG967. Regarding $\mathrm{Cl}^{-}$in the salt stress treatment, the levels in the leaves, stem and roots of AG967 genotype were 33, 16, and 9\% higher than in BRS323 (Figure 4C).

Salinity did not affect the concentrations of $\mathrm{K}^{+}$in the leaves and roots of BRS323 and increased by $89 \%$ the content in the stem (Figure 4B). In AG967, salt stress decreased $(33 \%)$ the $\mathrm{K}^{+}$concentration in the leaves and increased by 91 and $101 \%$, respectively, the content of this nutrient in the stem and roots.

Figure 5 shows the concentrations of $\mathrm{Na}^{+}, \mathrm{Cl}^{-}$ and $\mathrm{K}^{+}$in the $6^{\text {th }}, 7^{\text {th }}, 8^{\text {th }}$ and $9^{\text {th }}$ leaf pairs, counted from base of the stem, that is, from the oldest to the youngest fully expanded leaves. Salt stress increased $\mathrm{Na}^{+}$and $\mathrm{Cl}^{-}$ contents in all pairs of leaves of both sunflower genotypes in comparison to control conditions. However, these increases were more pronounced in AG967 genotype (Figure 5A and C).

The BRS323 genotype showed similar $\mathrm{Na}^{+}$ contents, regardless of the leaf age considered (Figure 5A). In contrast, the $\mathrm{Na}^{+}$content in the AG967 genotype increased progressively with leaf age (Figure 5A). Thus, the $\mathrm{Na}^{+}$content in the $6^{\text {th }}, 7^{\text {th }}, 8^{\text {th }}$ and $9^{\text {th }}$ pair of leaves of AG967 were respectively, 76, 52, 56 and 17\% higher than in the same pairs of leaves of the BRS323 genotype.

In the BRS323 genotype, the levels of $\mathrm{K}^{+}$were similar, regardless of treatment or pair of leaves evaluated (Figure 5B). In AG967, salt stress reduced the $\mathrm{K}^{+}$content in the $6^{\text {th }}$ and $7^{\text {th }}$ pairs of leaves by respectively, 77 and $54 \%$, compared to the same pairs under control conditions (Figure 5B). In contrast with $\mathrm{Na}^{+}$, the $\mathrm{K}^{+}$content in salt stress treatment was higher in the younger leaves.

Salinity changed the levels of $\mathrm{Na}^{+}$and $\mathrm{K}^{+}$in all organs of both genotypes, but they differ in accumulation of ions in the tissue. The leaves of salt-sensitive AG967 accumulated more $\mathrm{Na}^{+}$and less $\mathrm{K}^{+}$than salt-tolerant BRS323. In the stem and roots, the genotype AG967 concentrated more $\mathrm{K}^{+}$and less $\mathrm{Na}^{+}$than BRS323. Additionally, AG967 accumulated more $\mathrm{Na}^{+}$and less $\mathrm{K}^{+}$ in older leaves, in contrast to BRS323, whose contents of these ions did not differ between leaves.

Our results suggest that the retention of $\mathrm{Na}^{+}$in the stem and roots of BRS323 mitigated the harmful effects of this ion on the leaves (Figure 4), and indicate that this genotype has an important mechanism related to salt tolerance (Wu et al., 2019). Additionally, the ability of BRS323 to maintain the leaf $\mathrm{K}^{+}$content with a very low level of $\mathrm{Na}^{+}$gives this genotype a relatively better physiological state under salt stress. This response is also considered a mechanism of salt tolerance as it is a key factor in mitigating the deleterious effects of $\mathrm{NaCl}$-induced stress on plants (Abid et al., 2020).

The $\mathrm{Cl}^{-}$content in AG967 genotype was higher $(23 \%)$ in younger leaves ( $8^{\text {th }}$ and $9^{\text {th }}$ pairs) than in the older ones $\left(6^{\text {th }}\right.$ and $7^{\text {th }}$ pairs) (Figure $\left.5 \mathrm{C}\right)$, in contrast with BRS323, in which $\mathrm{Cl}^{-}$content was 33\% lower when compared the same pairs of leaves mentioned (Figure 5C).

The $\mathrm{Cl}^{-}$content in all organs of the AG967 genotype was higher than that of BRS323. The AG967 also had a remarkable high $\mathrm{Cl}^{-}$content in younger leaves, as opposed to that observed in BRS323. Li, Tester and Gilliham (2017) affirm that reduction of $\mathrm{Cl}^{-}$concentration in the xylem is a key step to reduce the $\mathrm{Cl}^{-}$toxicity, as it prevents a large accumulation in young tissues, indicating a greater selectivity in uptake and long-distance transport of this ion in salt-tolerant plants.

From the results of inorganic solutes, it can be hypothesized that the greater tolerance of BRS323 was, at least in part, due to physiological mechanisms of $\mathrm{Na}^{+}$ and $\mathrm{Cl}^{-}$exclusion and reduction of $\mathrm{K}^{+}$efflux from leaves, reducing the disturbances in ion homeostasis and in the cell metabolic activity of this genotype.

The addition of $\mathrm{NaCl}$ in the nutrient solution changed the levels of organic solutes in both genotypes, however, the reductions were more expressive in AG967 and the increases were more significant in BRS323 genotype (Figure 6A-D). Thus, salinity significantly decreased leaf contents of soluble carbohydrates (32\%), free amino acids (30\%), soluble proteins $(24 \%)$ and free proline $(29 \%)$ in AG967. In the roots, salt stress also decreased soluble carbohydrates and free amino acids (45 and 27\%, respectively) and increased soluble proteins by $28 \%$. However, in the BRS323 genotype, salt stress decreased only $14 \%$ the soluble proteins and increased proline $(41 \%)$ in leaves. In the roots, salinity decreased amino acids by $29 \%$, but increased soluble carbohydrates and proline by $45 \%$ and $111 \%$, respectively. 


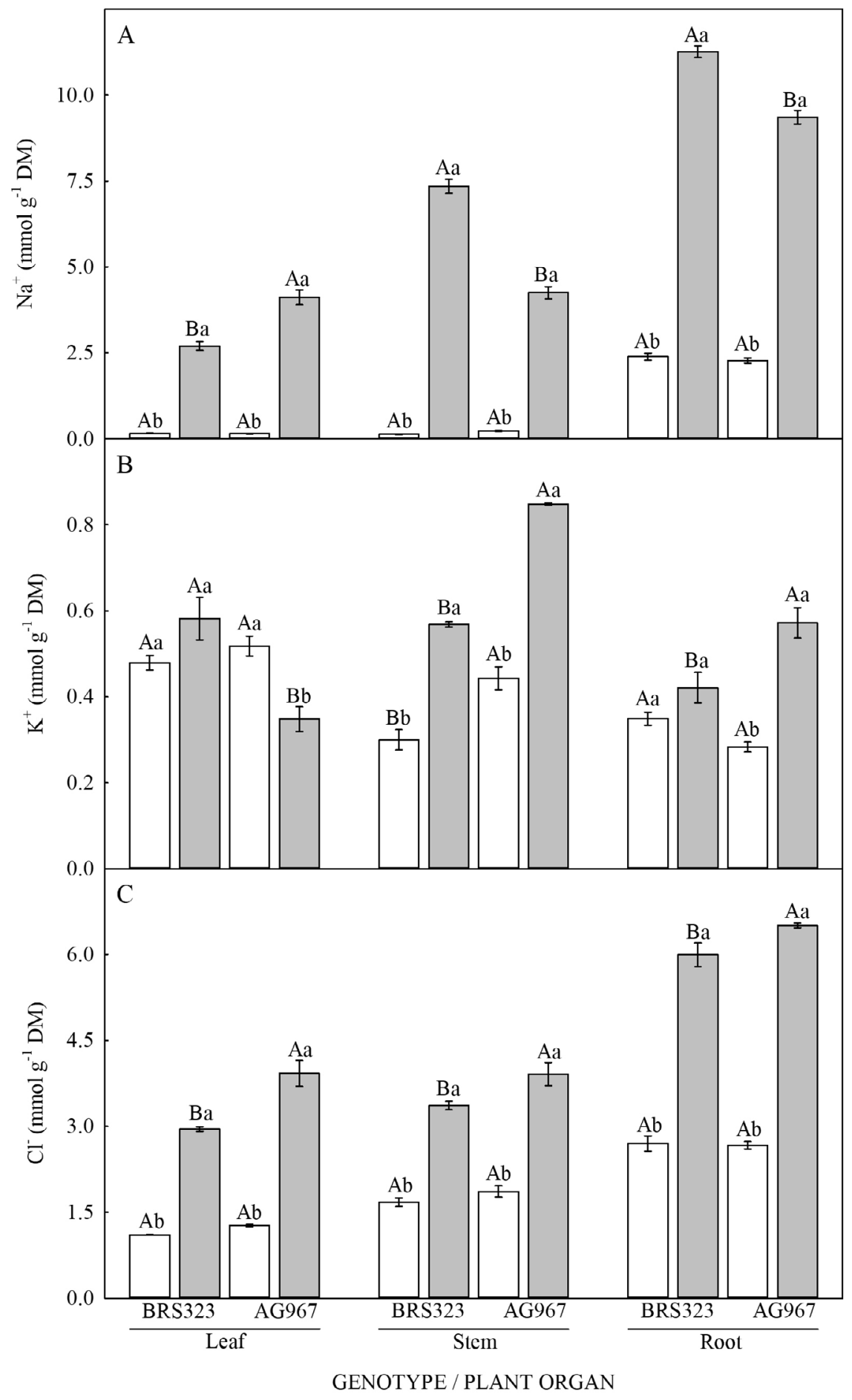

Figure 4: Sodium (A), potassium (B) and chloride (C) contents in leaves, stems and roots of two sunflower genotypes grown under greenhouse conditions for 20 days in nutrient solution - control ( $\square$ ) or nutrient solution containing $100 \mathrm{mM} \mathrm{NaCl}$ - salt stress (ם).

Means followed by the same letters do not significantly differ by the Tukey's test at $p \leq 0.05$. Uppercase letters compare genotypes at same salt levels and lowercase letters compare salt levels in same genotype. Vertical bars represent the standard errors ( $n=4)$. 


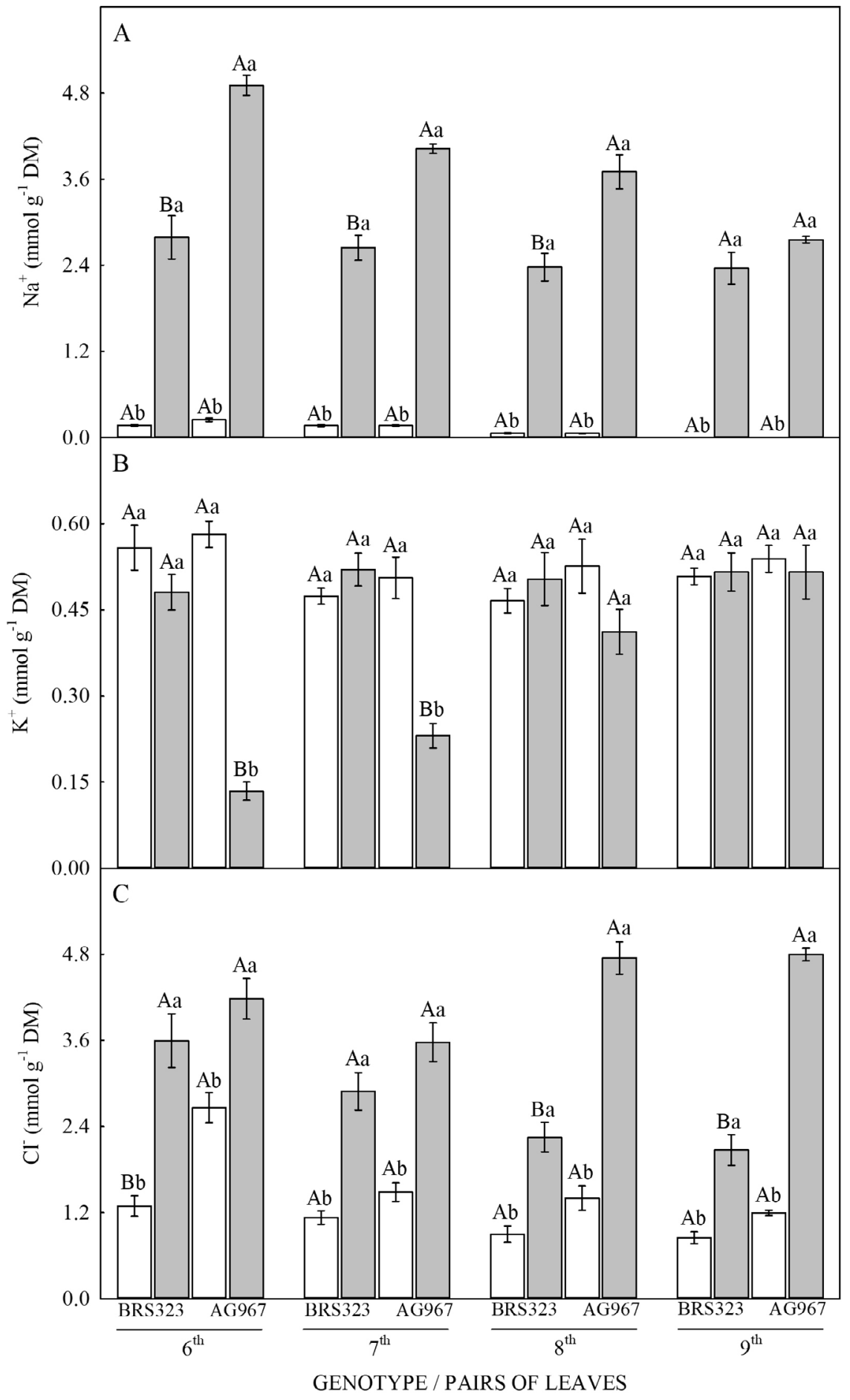

Figure 5: Sodium (A), potassium (B), and chloride (C) contents in leaves of different ages of two sunflower genotypes grown under greenhouse conditions for 20 days in nutrient solution - control ( $\square$ ) or nutrient solution containing $100 \mathrm{mM} \mathrm{NaCl}$ - salt stress (ם).

Means followed by the same letters do not significantly differ by the Tukey's test at $p \leq 0.05$. Uppercase letters compare genotypes at same salt levels and lowercase letters compare salt levels in same genotype. Vertical bars represent the standard errors ( $n=4)$. 


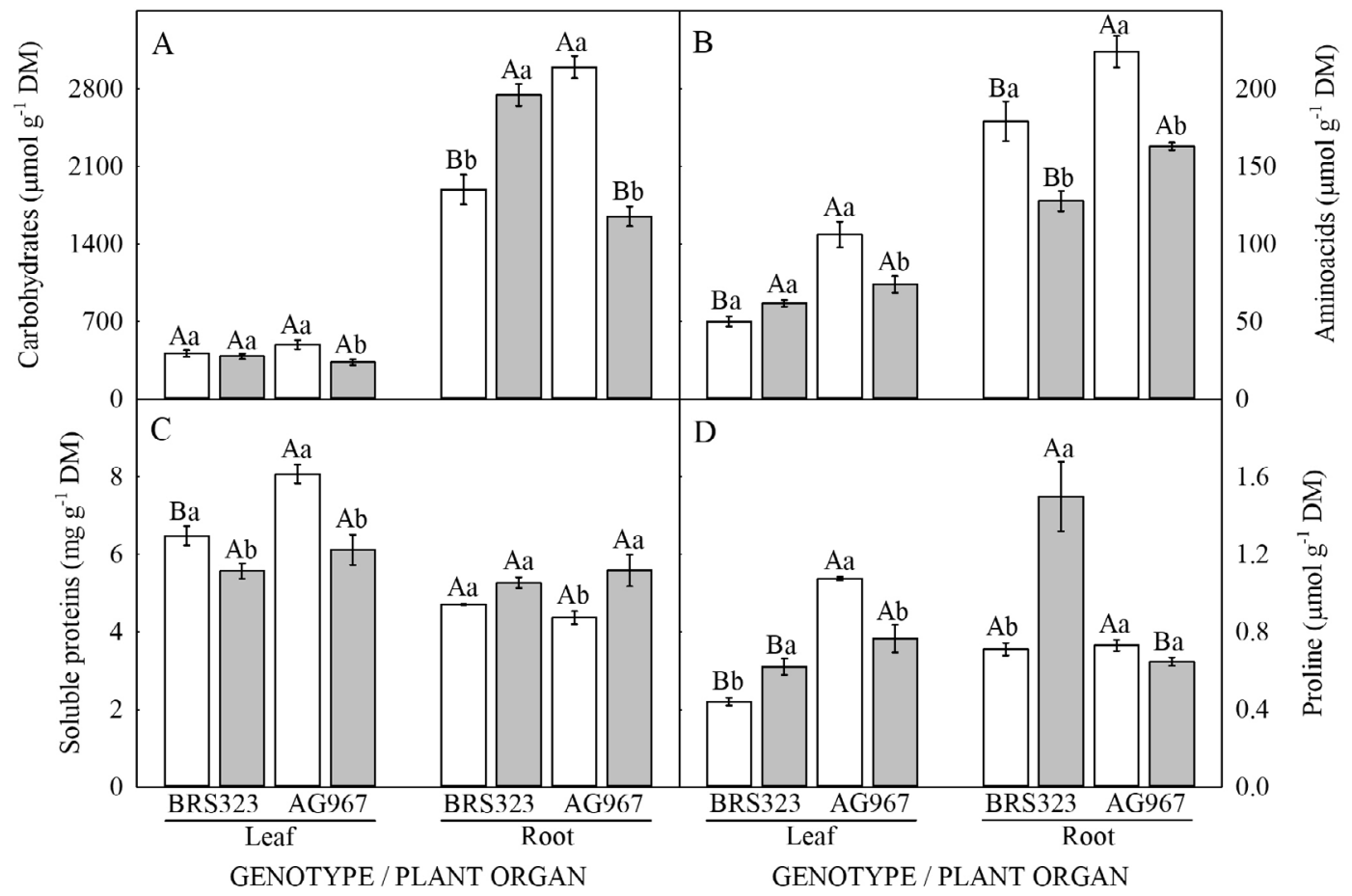

Figure 6: Carbohydrates (A), free amino acids (B), soluble proteins (C) and free proline (D) contents in leaves and roots of two sunflower genotypes grown under greenhouse conditions for 20 days in nutrient solution - control $(\square)$ or nutrient solution containing $100 \mathrm{mM} \mathrm{NaCl}$ - salt stress (ם). Additional details as in Figure 3.

Means followed by the same letters do not significantly differ by the Tukey's test at $p \leq 0.05$. Uppercase letters compare genotypes at same salt levels and lowercase letters compare salt levels in same genotype. Vertical bars represent the standard errors ( $n=4)$.

By comparing the genotypes in the stress treatment, substantial differences were not found between the leaf contents of each organic solute. However, in the stressed roots of BRS323, the levels of soluble carbohydrates and proline were 66 and 132\% higher than those of AG967, respectively.

For physiological level, the synthesis and accumulation of organic solutes (also known as compatible solutes or compatible osmolytes) in plants grown under salinity is an acclimation mechanism that enables the maintenance of turgor (Singh et al., 2015). In this study, salinity reduced the content of all organic solutes in leaves and the carbohydrates and amino acids in roots of salt-sensitive AG967 genotype. On the other hand, in BRS323, salinity increased the leaf and root proline contents and the root carbohydrates content. Furthermore, the levels of these solutes in the stressed roots of the BRS323, were substantially higher than those of AG967. Therefore, our results indicate that the leaves and roots of the BRS323 genotype had a much more efficient osmoregulation mechanism to cope with salt stress than that observed in saltsensitive AG967.
In higher plants, carbohydrate metabolism is co-regulated with amino acid metabolism and protein synthesis and involves reciprocal regulation. Amino acid biosynthesis uses carbohydrate backbones, while degradation of all amino acids produces carbohydrate backbones that can be converted into citric acid cycle intermediates and used as an energy source (Pratelli; Pilot, 2014). So, the decrease in photosynthesis was probably the critical factor for reducing the carbohydrates and amino acids contents in both leaves and roots of the AG967 (Abdul Qados, 2011), and can be an additional support to explain the salt-sensitivity of this genotype when compared to BRS323.

Regarding proline, the marked increase in proline content in both leaves and roots of BRS323 can be considered a biochemical trait related to tolerance to salt stress (Reddy et al., 2017). This compatible solute is reported to accumulate in response to several environmental stresses, but the role of proline in the osmotic adjustment is still controversial. In our study, the proline content in

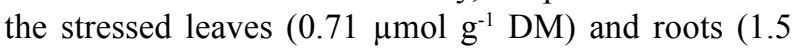


$\left.\mu \mathrm{mol} \mathrm{g}{ }^{-1} \mathrm{DM}\right)$ of BRS323 represented, respectively, 0.04 and $0.05 \%$ of the carbohydrates content $(1,892$ and 2,744 $\left.\mu \mathrm{mol} \mathrm{g}{ }^{-1} \mathrm{DM}\right)$, indicating that the contribution of proline to sunflower osmoregulation is negligible when compared to that of carbohydrates. These findings are in agreement with those obtained by other authors (Sacramento et al., 2014; Silva; Azevedo Neto; Gheyi, 2019; Cova et al., 2020).

In addition to its role in osmotic adjustment, a number of other functions are related to proline in plant acclimation to salt stress (Azevedo Neto; Silva, 2015). Thus, despite the minor importance for osmotic adjustment, our results suggest that the proline accumulation in leaves and roots does not exclude its beneficial role in the acclimation of sunflower plants to salt stress.

\section{CONCLUSIONS}

Genotypes AG963, AG967, BRS321, BRS324, $\mathrm{H} 251, \mathrm{H} 360$ and H863 were characterized as saltsensitive, especially AG967 genotype, while BRS323, Catisol, IAC-Uruguai, EXP11-26, EXP44-49, EXP60050, EXP887, HLA860HO and Olisun 5 were characterized as salt-tolerant, especially BRS323 genotype. The high $\mathrm{K}^{+}$ content and the low $\mathrm{Na}^{+}$content in the leaves were the ion traits related to salt tolerance in sunflower and can be used in breeding programs for this purpose. The better homeostasis in the mechanisms of transport, distribution and accumulation of inorganic solutes in conjunction with a more efficient osmoregulation mechanism through the synthesis of organic solutes may, at least in part, explain the greater salt-tolerance of BRS323 genotype in comparison to AG967.

\section{ACKNOWLEDGEMENTS}

Authors thank the Coordination for the Improvement of Higher Education Personnel (CAPES), the National Council for Scientific and Technological Development (CNPq), Bahia State Research Support Foundation (FAPESB), and the Federal University of Recôncavo da Bahia for the financial support over the years.

\section{REFERENCES}

ABDUL QADOS, A. M. S. Effect of salt stress on plant growth and metabolism of bean plant Vicia faba (L.). Journal of the Saudi Society of Agricultural Sciences, 10(1):7-15, 2011.

ABID, M. et al. Effect of salt stress on growth, physiological and biochemical characters off four kiwi fruit genotypes. Scientia Horticulturae, 271:e109473, 2020.
AZEVEdo NetO, A. D. de; SILVA, E. C. Physiology and biochemistry of salt stress tolerance in plants. In: CHAKRABORTY, U.; CHAKRABORTY, B. Abiotic stresses in crop plants. Wallingford: CABI, p.81-101, 2015.

BIRCK, M. et al. Performance of sunflower cultivars at different seeding periods in central Brazil. Ciência e Agrotecnologia, 41(1):42-51, 2017.

COVA, A. M. W. et al. Physiological and biochemical responses and fruit production of noni (Morinda citrifolia L.) plants irrigated with brackish water. Scientia Horticulturae, 260:e108852, 2020.

FERREIRA, D. F. SISVAR: A computer analysis system to fixed effects split plot type designs. Revista Brasileira de Biometria, 37(4):529-535, 2019.

GALILI, T. Dendextend: An R package for visualizing, adjusting, and comparing trees of hierarchical clustering. Bioinformatics, 31(22):3718-3720, 2015.

GERONA, M. E. B. et al. Physiological responses of contrasting rice genotypes to salt stress at reproductive stage. Rice Science, 26(4):207-219, 2019.

GONDIM, F. A. et al. Efeitos do $\mathrm{H}_{2} \mathrm{O}_{2}$ no crescimento e acúmulo de solutos em plantas de milho sob estresse salino. Revista Ciência Agronômica, 42(2):373-381, 2011.

HOAGLAND, D. R.; ARNON, D. I. The water-culture method for growing plants without soil. Circular. California Agricultural Experiment Station, 347(2):1-32, 1950.

HURA, T. et al. Physiological responses of Rosa rubiginosa to saline environment. Water Air Soil Pollut, 228(81):1-11, 2017.

INSTITUTO BRASILEIRO DE GEOGRAFIA E ESTATÍSTICA - IBGE. Levantamento sistemático da produção agrícola. 2019. Available in:<https://sidra.ibge.gov.br/home/lspa/brasil>. Access in: September, 02, 2020.

ISAYENKOV, S. V.; MAATHUIS, F. J. M. Plant salinity stress: Many unanswered questions remain. Frontiers in Plant Science, 10:1-11, 2019.

JOLLIFFE, I. T.; CADIMA, J. Principal component analysis: A review and recent developments. Philosophical Transactions of the Royal Society A, 374(20150202):1-16, 2016.

JONES, JR. J. B. Laboratory guide for conducting soil tests and plant analysis. Boca Raton: CRC Press, 2001. 384p.

KASSAMBARA, A.; MUNDT. F. Factoextra: Extract and visualize the results of multivariate data analyses. $R$ package version 1.0.7, 2020. Available in: <http://www.sthda.com/english/ rpkgs/factoextra>. Access in: January, 20, 2020. 
LI, B.; TESTER, M.; GILLIHAM, M. Chloride on the move. Trends in Plant Science, 22(3):236-248, 2017.

LI, W. et al. A salt tolerance evaluation method for sunflower (Helianthus annuus L.) at the seed germination stage. Scientific Reports, 10:e10626, 2020.

LIANG, W. et al. Plant salt-tolerance mechanism: A review. Biochemical and Biophysical Research Communications, 495(1):286-291, 2018.

LIU, Y. et al. Assessment of drought tolerance of 49 switchgrass (Panicum virgatum) genotypes using physiological and morphological parameters. Biotechnology for Biofuels, 8(1):152, 2015.

MACHEKPOSHTI, M. F. et al. Effect of irrigation with sea water on soil salinity and yield of oleic sunflower. Agricultural Water Management, 188:69-78, 2017.

MAECHLER, M. P. et al. Cluster: Cluster analysis basics and extensions. R package version 2.1.0., 2019. Available in: <https://cran.r-project.org/web/packages/cluster/>. Access in: January, 20, 2020.

MELO, E. N. et al. Evaluation of West Indian cherry (Malpighia emarginata) rootstock under saline water irrigation and nitrogen fertilization. Australian Journal of Crop Science, 12(06):1034-1040, 2018.

MUNNS, R. Comparative physiology of salt and water stress. Plant, Cell and Environment, 25(2):239-250, 2002.

NOBRE, R. G. et al. Produção de girassol sob estresse salino e adubação nitrogenada. Revista Brasileira de Ciência do Solo, 35(3):929-937, 2011.

PRATELLI, R.; PILOT, G. Regulation of amino acid metabolic enzymes and transporters in plants. Journal of Experimental Botany, 65(19):5535-5556, 2014.

R DEVELOPMENT CORE TEAM. R: A language and environment for statistical computing. 2020. R Foundation for Statistical Computing, Vienna, Austria. Available in: <https://www.rproject.org/>. Access in: January, 20, 2020.

RAHNAMA, A. et al. Growth properties and ion distribution in different tissues of bread wheat genotypes (Triticum aestivum L.) differing in salt tolerance. Journal of Agronomy and Crop Science, 197(1):21-30, 2011.

REDDY, I. N. B. L. et al. Salt tolerance in rice: Focus on mechanisms and approaches. Rice Science, 24(3):123-144, 2017.
RHODES, D.; NADOLSKA-ORCZYK, A.; RICH, P. J. Salinity, osmolytes and compatible solutes. In: LAÜCHLI, A.; LÜTTGE, U. Salinity: Environment - plants - molecules. Dordrecht: Kluwer Academic Publishers, p.181-204, 2002.

SACRAMENTO, B. L. et al. Pigmentos e teores de solutos orgânicos em plantas de aguapé sob estresse salino. Enciclopédia Biosfera, 10(18):33-44, 2014.

SAKINA, A. et al. Genetic variation for salinity tolerance in pakistani rice (Oryza sativa L.) germplasm. Journal of Agronomy and Crop Science, 202(1):25-36, 2016.

SANTOS, J. B. et al. Irrigation with saline water and nitrogen in production components and yield of sunflower. Revista Caatinga, 29(4):935-944, 2016.

SARABI, B. et al. Multivariate analysis as a tool for studying the effects of salinity in different melon landraces at germination stage. Notulae Botanicae Horti Agrobotanici Cluj-Napoca, 44(1):264-271, 2016.

SHAHZAD, A. N. et al. Maize genotypes differing in salt resistance vary in jasmonic acid accumulation during the first phase of salt stress. Journal of Agronomy and Crop Science, 201(6):443-451, 2015.

SHTEREVA, L.; VASSILEVSKA-IVANOVA, R.; KARCEVA, T. Effect of salt stress on some sweet corn (Zea mays $L$. var. saccharata) genotypes. Archives of Biological Sciences, 67(3):9931000, 2015.

SILVA, P. C. C.; AZEVEDO NETO, A. D. de; GHEYI, H. R. Mobilization of seed reserves pretreated with $\mathrm{H}_{2} \mathrm{O}_{2}$ during germination and establishment of sunflower seedlings under salinity. Journal of Plant Nutrition, 42(18):23882394, 2019.

SINGH, M. et al. Roles of osmoprotectants in improving salinity and drought tolerance in plants: A review. Reviews in Environmental Science and Bio/Technology, 14(3):407426, 2015.

VAN ZELM, E.; ZHANG, Y.; TESTERINK, C. Salt tolerance mechanisms of plants. Annual Review of Plant Biology, 71(1):403-433, 2020.

WU, W. et al. Hydrogen peroxide as a mediator of 5-aminolevulinic acid-induced $\mathrm{Na}^{+}$retention in roots for improving salt tolerance of strawberries. Physiologia Plantarum, 167(1):5-20, 2019. 